TANULMÁNYOK 2019/2. Bölcsészettudományi Kar, Újvidék

STUDIJE 2019/2. Filozofski fakultet, Novi Sad

STUDIES 2019/2. Faculty of Philosophy, Novi Sad

ETO: 821.511.141-311.1KARINTHY F.

ORIGINAL SCIENTIFIC PAPER

DOI: $10.19090 / \mathrm{tm} .2019 .2 .119-127$

A kézirat leadásának időpontja: 2019. november 13.

Közlésre elfogadva: 2019. november 15.

\author{
LÁBADI Lénárd \\ Újvidéki Egyetem, Bölcsészettudományi Kar \\ Magyar Nyelv és Irodalom Tanszék \\ Újvidék, Szerbia \\ llenardvienna@gmail.com
}

\title{
KARINTHY FRIGYES SZERTEÁGAZÓ TEST-FILOZÓFIÁJA
}

\author{
Karintijeva višeslojna filozofija tela
}

\section{Karinthy's Extensive Body Philosophy}

Jelen tanulmány célja azoknak a test-elméleti meghatározásoknak a vizsgálata, amelyek Karinthy Frigyes Utazás a koponyám körül című „betegségnaplójában” megjelennek. A kötetben kidolgozott korporeális gondolkodást az agydaganat kialakulása hívja életre. A tanulmány sorra veszi az Utazás a koponyám körül című művében azokat a megfogalmazásokat, amelyek az alapvető testi funkciók és érzékelések sajátos elméleti újraértékeléséhez vezetnek. Az író test-elméleti meglátásai Csabai Márta, Erős Ferenc, P. Müller Péter, Jean Starobinski és Széplaky Gerda idevonatkozó meghatározásaival kerülnek párhuzamba. A rák okozta testi funkciózavarok „megszövegezése” Karinthy munkáját rokoníthatóvá teszi Babits „beszélgetőfüzeteivel”, Esterházy Hasnyálmirigynaplójával és Kosztolányi „beszélgetőlapjaival” egyaránt. A naplók egybecsengései jól bizonyítják, hogy a betegség jelenléte hasonló irodalmi mechanizmusokat generál.

Kulcsszavak: Karinthy Frigyes, „betegségnapló”, daganat, testkép, test-filozófia

Karinthy Frigyes Utazás a koponyám körül című szöveg tanúsága szerint a központi idegrendszer müködését hátráltató agytumor megléte a szerzőt olyan fizikai és szellemi küzdelmekre kényszeríti, amely sok esetben az általános testi müködések és észlelések kényszeres felülvizsgálatát eredményezi. Az emberi szervezet rendeltetéséről való gondolkodást a testi funkciózavarok generálják. Karinthy szövegében a diagnózisok egzakt és a vizsgálatok újszerü leírásán túl kibontakozik egy olyan sajátos korporeális filozófia, amely kiterjed többek között 
a „testrészek kettős szerepére”, a „test és lélek különállóságára”, az „asztrál test” kialakulására, a daganat evolúciós rendeltetésére is.

Az Utazás a koponyám körül című szöveget Z. Varga Zoltán meghatározásából kiindulva jelen tanulmány „betegségnaplónak” tekinti, mivel megalkotásának miértje a betegség okozta „válsághelyzetben” keresendő (Z. Varga 2016, 952).

A szöveg kezdetén, amikor a tünetek és a hallucinációk még csak halványan jelentkeznek, Karinthy a fülére gyanakszik, valamiféle összegyült zsiradékra, amely hallását nehezíti. A tisztaság, a testi rendezettség és az emberi hiúság kapcsán fogalmazza meg a „testrészek kettős funkciójáról” szóló nézeteit. Véleménye szerint a legtöbb emberi testrész alapvető esztétikai és csábító szereppel, elemi szexuális funkcióval is rendelkezik. A fülnek, a szájnak és a szemnek tulajdonítja ezt a kettős attribútumot.

Kieszeltem, hogy az élő testnek, végig a természetben kettős jellege van: egy belügyi, életfenntartó, vagy mondjuk így szexuális. Ennek megfelelően minden szervünk kétféle, egészen különböző célra és feladatra van berendezve; a szem nemcsak látószerv, de vonzó ékszer is, örökmécs, mely magába szédíti a másnemủ embert, a fül nemcsak arra való, hogy halljunk vele, de arra is, hogy enyelegve cibáljuk, s a száj, a szerelmes ifjú számára nem a bélcsatorna felső nyílása, evésre való eszköz, hanem maga a megtestesült csók (Karinthy 1991, 21).

A funkcionális és szexuális rendeltetésű korporeális elmélettel szemben, amely az ember részeit annak elevenségében veszi szemügyre, megjelenik a „test és lélek kölcsönhatásáról" kialakított teória is. Eszerint a hamvasztás a lelket is elpusztítja, mivel - Karinthy vélekedése szerint - az „asztrál testünk” a halálunk után eleven szöveteinkből teremtődik meg.

A holttest nem olyan nagyon halott valami, mint ahogy hisszük, vagy legalábbis nem lehet tudni biztosan, nincs-e rá szükség: nem is a természetre gondolok, a nitrogénre, ami a növényeknek kell, de hátha egyszer kiderül, hogy nekünk magunknak, a lelkünknek, vagy annak a valaminek, amit így hívunk, fontos, hogy éppen így, ilyen lassan bomoljon fel, ahogy szokott - talán az asztráltest ebből a maradékból szedi össze a maga finom anyagát (Karinthy 1991, 25).

Karinthy az idézett gondolatsorban a test érzékeny anyagának „erőszakos”, mesterséges megsemmisítése ellen lép fel. A természetes folyamatokban hisz, a szellem létezésében, a túlvilág felé mutató energiákban. A sors fintora talán, hogy mindennek ellenére mégis rajta végzik el Európában elsők között a rendkívül nagy kockázattal járó beavatkozást. 
A daganat elhatalmasodása idegen testi mechanizmusokat generál. Karinthy a saját testének irányíthatatlanságával szembesül. A betegségnek ebben a stádiumában fogalmazódik meg a „test és szellem különállóságának” gondolata. A koordináció és a test általános állapotának fokozott romlása szellemi hanyatlást nem eredményez. Karinthy gondolatai épek, akár a betegsége előtt. Úgy érzi, hogy teste valaki másnak, az én mellé beférkőzött entitásnak engedelmeskedik, amelyet lázadó „különlélekként” interpretál.

Öszintén jólesik, hogy test és lélek kettősségét, amiben hiszek, alkalmam van kísérletileg ellenőrizni - hiszen, lám, teljes tudatomnál vagyok, normálisan érzek és helyesen gondolkozom, és a testem mégsem engedelmeskedik, illetve engedelmeskedik, de nem nekem. Valaki másnak, aki belém bújt. Külön lelke van a testnek, az „,én”-től független, és a különlélek most ellenem fordult, fellázítja ellenem a testet (Karinthy 1991, 133).

A diagnózis megszületése után, a vizsgálatok közepette, a koponyájában megbúvó daganatról egy „új és ismeretlen emberi szervként” kezd el gondolkodni, amely akár az eddig felfoghatatlan rezgések érzékelésére is szolgálhat. „Hátha egy új, még ismeretlen szerv első, primitív, öntudatlan, vagy céltudatos próbálkozása a daganat - új szervé vagy testrészé, amely meg akar születni...” (Karinthy 1991, 147). Elméletét valamivel később a következőképpen folytatja: „(v)agy a nyúltagyvelő titkos utasítására, hevenyészett vázlatot készített, egy új érzékszerv tervrajzát, mely másféle erők sugárzását közvetíti a központba, mint amiket eddig közvetített? Szerves elektroszkópot, vagy szerves antennát (amilyen nyilvánvalóan a rovaroknak is van)" (Karinthy 1991, 147).

Nem meglepő Karinthy sajátos felfogása, amely közelebb áll a sci-fi irodalmához, mint az egzakt orvostudományhoz. Ennek oka, hogy az onkológia új és feltérképezetlen területére kényszerült lépni. A szakkönyvek tájékozatlansága, valamint a kísérletek és a gyógyult páciensek hiánya teret engedett Karinthy határtalan képzelete számára, hogy megalkossa saját elméletét a daganatok kialakulásának okáról.

Szalay Károly úgy véli, hogy a „betegségnapló” elején leírt filmvetítés azt a célt szolgálja, hogy felkészítse az olvasót a fö attrakcióra, a tényleges operációra (Szalay 1961, 292). Ahogyan a szövegben Olivecrona valóságos alakja párhuzamban áll Olson Irjő fiktív személyével (Karinthy 1991, 152), úgy viszonyul a tájékoztató jellegü film a valóságos mütéthez. A mozgóképen egy epilepsziás betegen végeznek koponyamütétet. Itt, a későbbi valós beavatkozással ellentétben, Karinthy hideg tárgyiassággal számol be a történtekröl, víziós elemek nélkül:

Az asztalra szíjazott betegnek csak a fejét látni, a tanár nekimegy, elegáns mozdulatokkal előbb megskalpolja, a fejbőrt hátrahajtja, aztán egy perfo- 
ráló nagy fúróval körbelyukasztja a koponyát, majd leemeli a fejről, mint valami sapkát. Az agyhártyát - olyan, mint egy hajlekötő háló, szinte természetellenes - tisztán, gusztusosan szétvágja, az agyvelő kocsonyáját látni, ahogy remeg és lötyög a csontcsészében (Karinthy 1991, 19).

Csabai Márta és Erős Ferenc a Testhatárok és énhatárok című test-elméleti kérdésekkel foglalkozó tanulmányban hangsúlyozzák, hogy Arthur Frank „az egészség-betegség viszonylatában” négy „test/szelf típust különít el, amelyek jellemző módon reagálnak a test funkciózavaraira, a betegségre, és ezeket a viszonyulásokat sajátos »test-narratívumok « formájában jelenítik meg” (Csabai-Erős 2000, 143). Az Arthur Frank-féle „fegyelmezett, tükröző, uralkodó és kommunikatív” típus közül Karinthy „korporeális felfogása” mindvégig az „uralkodó test/szelf” definíciójának felel meg. Ez „az erő által definiálja magát, így soha nem fogadja el a kontrollvesztést, a betegség esetlegességét" (Csabai-Erős 2000, 142-143). Az Utazás a koponyám körülben az elbeszélő aggódó tekintete mindvégig testének változásait figyeli, latba veszi a jellegzetes szimptómák sorát, orvosi könyveket lapozgat. Így jutunk el a biztos diagnózis megállapításához, jóval az orvosok képalkotó vizsgálatai előtt. Sőt még az operáció alatti kötelező éberség is Karinthy „uralkodó test/szelf típusát” szolgálja.

A stockholmi operáció menete alatt a beteg teste mindvégig arccal a padló felé fordítva fekszik. Csupán néhány részlet rajzolódik ki tekintete előtt. Teste „mintha elkülönült létezővé, az éntől függetlenné válna, így mintegy »felajánlja magát « a beavatkozásra” (Csabai-Erős 2000, 142). Az orvos köpenyének sötét pöttyeiből a vágások és a szúrások okozta folytonos vérzésre asszociál. „Zsebkendő nagyságú darabot rekonstruálok az előttem lebegő fehér köpeny aljából. Fekete pontok tarkítják, mint a babos kendőt. Persze az ütőerek nem folyatnak, ugrásszerüen fecskendeznek" (Karinthy 1991, 164). Beszükült látótere miatt az érzékszervei közül csak a hallására és a hőérzékelésére hagyatkozhat. A müszerek zajából és a tapintásokból vonja le következtetéseit. „Puha tojások, félrehajtások, a koponya biztosan szabad már, a bőnye, tarkómon, visszaugrott. Hallom, ahogy a trepan koppan, immár harmadszor” (Karinthy 1991, 164). „Minden egyes mozzanat reflexiókat vált ki belöle, a halál mezsgyéjén állva közöl riportot a majdnem túlvilágról" (Szalay 1987, 250).

A beavatkozás Karinthy általi dokumentálása a „boncszínházak” egykori atmoszféráját és eljárásait eleveníti fel. P. Müller Péter a következőképpen írja le a múltbeli anatómiai prezentációk menetét:

A boncszínházak az egyetemi városokban alakultak ki, ahol alkalmanként több száz érdeklődő nézhette a holttest felnyitásának procedúráját. Az esemény voltaképpen demonstráció volt, annak a nézetnek a 
szemléltetése, hogy a testen belül ugyanaz a rend uralkodik, mint azon kívül. Így a nyilvános boncolás valójában egy olyan ritualizált drámai elöadás, olyan „szent anatómia”, amely a test megnyitásának jóvátételéről szól: ismeretelméleti kíváncsiság, melyet nyilvános megbánás követ. Kezdetben az esemény szereposztása három közremüködőt igényelt, a tetemet, a sebészt és a professzort, akik a nézőközönség előtt azt illusztrálták, hogy a tudás könyveiben rögzített ismeretek visszaigazolódnak a természetben (a testben). A tetem tehát a szemléltető eszköz pedagógiai szerepét töltötte be (P. Müller 2009, 202-203).

A „betegségnaplóban” mindvégig nyomon követhető a kíváncsiság, a folyamatok egymásutániságának, a reakciók kapcsolatrendszerének megfigyelése iránti lankadatlan érdeklődés. A stockholmi koponyamütét „színházának” kíváncsi tömegét az olvasó képezi. Karinthy egyazon személyben testesíti meg az operáció alanyát és a folyamatok narrátorát is. Benne egyesül a beavatkozás „teteme” és a sebész munkáját értelmezo „professzor” szerepköre is. A kimért „boncszínházszerü” folyamatábrázolások azonban néhol a rombolás katartikus élvezetébe csapnak át: „A művelet brutalitása magával ragad. Vad gyönyörüséggel adom át magam, szinte segíteni szeretnék. Lihegve biztatom magamban a tanárt, a rombolás dühe átcsap rám. Vágd csak, törd csak jobban, csak neki csak szét az egészet" (Karinthy 1991, 165).

Míg Karinthy esetében a test belső régiói válnak a külvilág számára nyitottá, hozzáférhetővé, addig Babits „beszélgetőfüzeteiben” és Kosztolányi „beszélgetőlapjain” a külső, mesterségesen megalkotott tárgyak kerülnek a testen belülre, mivel esetükben a táplálás kanülön keresztül zajlik. A kitüremkedő csövek különálló testrészként kibővítik Babits és Kosztolányi testének határait. A szerkezet megfelelő müködése a nyugalom érzését, míg meghibásodása akár a halált is eredményezheti. „Ha kiveszik a kanült, a légcső megint / összelappad és megfulladhatok" (Babits 1980, 52). Az orvosi segédeszközök testen belüli alkalmazása az undor érzését keltik. „De undorított. 2 bennem marad-hatott" (Kosztolányi 2010, 280).

Széplaky Gerda A halott test grammatikája címü tanulmányában Borbély Szilárd $A$ Testhez címü verseskötetének szövegeit vizsgálja. Széplaky szerint alapvetö, ösztönös félelmünk a test kiszolgáltatott állapotaiban, sebezhetőségében gyökerezik. Ennek a félelemnek a valóságát azzal magyarázza, hogy „a test a lehetőségfeltétele mindennek, nemcsak az életnek, a mozgásnak, a cselekvésnek, hanem még a nyelvnek is, a szó kimondásának" (Széplaky 2011, 147). Széplaky gondolatainak tükrében megállapítható, hogy Karinthy félelme a test fölötti kontrollvesztésben, a betegségnek való kiszolgáltatottságban gyökerezik. 
Amikor az operáció alatti érzékelés „valódisága” már erősen megkérdőjelezhető, akkor Karinthy az asszociációk sokaságába merülve vonja ki magát az erőszakos folyamatok rengetegéből. Nem történik más a képzelgés folyamatában, mint hogy „a tekintet végső fokon meghaladja önmagát, és saját célját keresi a látás önmegtagadó és önfeláldozó tettében" (Starobinski 2006, 37). Tehát a beavatkozás szituációjában, a heves víziók csúcsán „[a] tekintet nehezen éri be a látszat puszta megfigyelésével. Saját természetéből fakadóan többet követel" (Starobinski 2006, 35). Ez a technika a szellem megcsonkításától való félelemben alkalmazódik, mivel az órák és a napok, a hallucinációk és a valóságos tapasztalatok közötti határvonalak fátyolossá válnak. „Ha most meg tudom határozni, hogy hova raktam el a töltőtollamat, a szobámban, az éjjeliszekrény fiókjában, akkor eszméleten vagyok. Nem, nem, ez se jó, inkább azt a, igen, azt a balladát, azzal az időt is mérni tudom, eltart egy negyedórát, elejétől végig" (Karinthy 1991, 167). Azonban minden asszociációs technika ellenére a valóság biztos vonala megtörik, és hallucinációk közepette eljutunk a daganathoz, a szöveg születésének centrumához és okához.

Ahogyan Esterházy szövegében a rák Hasnyálmirigy kisasszonyként kerül kapcsolatba az íróval („Le kéne írni ezt a hogyishívjákot, hogyan néz ki. Legyen fiatal, ennyi [újabb] közhely vállalható. Hallod, Hasnyálka? Jó vagy - nekem. [...] Szóval, Hasnyálka legyen egy dögös csaj. Igen, de mégse így. Elég magas, 170 fölött, magas sarkúban ez már jelentős. De hogyan göngyölődik belém?” [Esterházy 2016, 24]), úgy Karinthy esetében is női alakban jelenik meg az elváltozás. Ebben az esetben a daganat felértékelődik, és szakrális színezetet kap. Egymásba simul a gyülölt betegség és a szeretett test képe. A benső ismeretlensége a testbe kódolt isteni princípiumot hordozza magában, amelyhez a szerző hozzáférkőzik, kapcsolatot teremt vele. A daganattal való találkozás, amely Karinthy egyik víziójában valósul meg, a Szűz Mária és a kis Jézus-ábrázolásokat idézi. A szent ismeretlen közelsége azonban nem a tiszteletet, a csodálatot, hanem a pusztítás aktusát provokálja.

Most meglátja a vérdaganatot. Ott fekszik, kicsit oldalt, a hólyag belsejében, vörös, jókora göb: a hólyaggal együtt akkora, mint egy kis kelvirág. Felülete dudoros. A dudorokból rajz alakul ki, vagyis dombormü. Mint egy nagy kámea, amibe saját anyagából mintát véstek. A minta elmosódottan, női felsőtestet ábrázol - karjaiban erős arcához szorítva, pufók csecsemőt tart. Az anya fején olaszos csipkekendő, a bambino profilban fordul, belekapaszkodik az anya nyakába. Szinte kár érte, hogy most pusztítani kezdi. Körülégeti, óvatosan, de irgalmatlanul, a kámeát, melynek egész tömege élesen elemelődik a környező, sárga szövettől (Karinthy 1991, 179-180). 
Ha Széplaky Gerda Borbély Szilárd kötetére kidolgozott gondolatmenetét rávetítjük Karinthy operációélményére, akkor rájövünk, hogy az eröszakos mozdulatlanságban töltött idő maga a testi halál állapota. „A halál aktusa mindig agressziót hordoz, mert mindig az erőszakos megszakítását jelenti valami folytonosnak, egy adott minőségből átlépünk egy radikálisan más minőségü létállapotba: a létből a nem-létbe. A halál a testet a két alapvető létlehetőségével szembesíti: az életteliséggel és a mozdulatlansággal" (Széplaky 2011, 151). Az „erőszakos” éber operáció állapotában Karinthy teste maga az élő halál. Kényszerített mozdulatlanságában csak a gondolatai felett uralkodhat. Története folyamán a beavatkozás ideje alatt válik a legkiszolgáltatottabbá, a benne fészkelő daganat és az orvostudomány számára egyaránt.

Karinthy betegsége egy olyan tömör és termékeny periódussal ajándékozta meg az írót, amely részben sajátos test- és betegségelméleti nézeteinek kidolgozásához vezetett. Jól megfigyelhető, hogy a szimptómák és az orvosi beavatkozások súlyosbodásával a testtel kapcsolatos megfigyelések mindinkább a vízió és a fantázia területére helyeződnek át.

Véleményem szerint nemcsak a tájékoztató jellegü film leírása készíti fel az olvasót az operációra, ahogyan ezt Szalay Károly állította, hanem a kötet minden egyes test-funkcióval foglalkozó része is ezt a célt szolgálja. A „testrészek kettős szerepének" meghatározása elvezeti az olvasót a daganat „új emberi szervként” való leírásához. A két elmélet kiegészíti egymást, s Karinthy célja ezzel az, hogy a tumor többfunkciós testi elemként is értelmezhető legyen. Minden szöveg eleji feltételezés a daganatot egy olyan titokzatos tudományosságba burkolja, amely a kóros elváltozással való „találkozás pillanatában” víziós elemekre hullik szét. A „test és lélek különállóságát”, a „különlélek” jelenlétét taglaló szövegrészlet az operáció alatti lelki szárnyaláshoz, gazdag látomásossághoz vezet el minket. E jelenség bemutatása a mütét alatt igazolja, hogy amíg a test „halott mozdulatlanságban” fekszik, addig a lélek szabad „különállóságban” létezhet.

A fenti megállapítások tükrében kitünik, hogy a „betegségnaplóban” kidolgozott összes test-elméleti részlet a koponyamütét „színházának” egy-egy elemét és „felvonását” vezeti fel, támasztja alá. Azonban a gyógyulás idején, amikor a szervezet belső és külső egysége újra helyreállni látszik, a figyelmet a test a daganat hiányában már nem képes a kóros vészjelzésekre összpontosítani, ehelyett már az új és ismeretlen élettapasztalatok keresésére helyeződik a hangsúly.

\section{Források}

Babits Mihály. 1980. Babits Mihály beszélgetőfüzetei I-II., szerk. Belia György. Budapest: Szépirodalmi Könyvkiadó.

Esterházy Péter. 2016. Hasnyálmirigynapló. Budapest: Magvető. 
Karinthy Frigyes. 1991. Utazás a koponyám körül. Györ: Editorg Kiadó.

Kosztolányi Dezső. 2010. „most elmondom mint vesztem el”: Kosztolányi Dezső betegségének és halálának dokumentumai, szerk. Arany Zsuzsanna. Pozsony: Kalligram Könyvkiadó.

\section{Irodalom}

Csabai Márta-Erős Ferenc. 2000. Testhatárok és énhatárok: Az identitás változó keretei. Budapest: Jószöveg Műhely Kiadó.

P. Müller Péter. 2009. Test és teatralitás. Budapest: Balassi Kiadó.

Starobinski, Jean. 2007. Poppea fátyla: Jean Starobinski válogatott irodalmi tanulmányai, szerk. Szávai Dorottya. Ford. Ádám Anikó-Földes Györgyi-Hardi Ferenc-Martonyi ÉvaLőrinszky Ildikó-Papp Ágnes Klára-Radvánszky Anikó-Szávai Dorottya. Budapest: Kijárat Kiadó.

Szalay Károly. 1961. Karinthy Frigyes. Budapest: Gondolat.

Szalay Károly. 1987. „Elmondom hát mindenkinek”: Karinthy Frigyes életéről és müveiről 1887-1938. Budapest: Kossuth Könyvkiadó.

Széplaky Gerda. 2011. A halott test grammatikája: A megváltás lehetetlensége Borbély Szilárd A Testhez. Ódák \& Legendák címü verseskötetében. Helikon 57 (1-2): 141-156.

Z. Varga Zoltán. 2016. Időszivárgás és ólomszív. Jelenkor 59 (9): 951-957.

\section{Lenard LABADI}

\section{KARINTIJEVA VIŠESLOJNA FILOZOFIJA TELA}

Cilj ove studije je izučavanje telesno-teorijskih definicija koje se pojavljuju u „dnevniku bolesti“ pod naslovom Utazás a koponyám körül [Putovanje oko moje lobanje] Friđeša Karintija. Telesno razmišljanje istkano u ovom delu nastalo je Karintijevim obolevanjem od tumora mozga. Rad se bavi analizom delova teksta koji vode do svojevrsnog teorijskog preispitivanja osnovnih telesnih funkcija i čula. Piščeva telesno-teorijska viđenja posmatraju se paralelno sa relevantnim definicijama Marte Čabai, Ferenca Ereša, Petera P. Milera, Žana Starobinskog i Gerde Seplaki. „Tekstualizacija“ telesnih disfunkcija izazvanih rakom čini Karintijev rad sličnim Babičevim „razgovornim sveskama“, Esterhazijevim „dnevnikom pankreasa“ i Kostolanjijevim „razgovornim listovima“. Sazvučja ovih dnevnika dokazuju da prisustvo bolesti generiše slične književne mehanizme.

Ključne reči: Friđeš Karinti „dnevnik bolesti“, tumor, slika o telu, telesna filozofija

\section{Lénárd LÁBADI}

\section{KARINTHY'S EXTENSIVE BODY PHILOSOPHY}

The aim of this study is to look into the body-theoretical definitions that appear in the "diary of an illness", entitled Utazás a koponyám körül [A Journey Around My Skull] by Frigyes Karinthy. The body-thinking emphasized in this work arose due to the development of Karinthy's 
brain tumor. The paper deals with the analysis of the parts of the text which leads to a kind of theoretical re-evaluation of the basic bodily functions and senses. The writer's bodytheoretical perceptions are viewed in parallel with the relevant definitions of Márta Csabai, Ferenc Erős, Péter P. Müller, Jean Starobinski and Gerda Széplaky. The "textualisation" of cancerinduced bodily dysfunctions makes Karinthy's work similar to Babits's "talkbooks", Esterházy's "pancreatic diary" and Kosztolányi's "talk sheets". The consonance of the diaries well demonstrates that the presence of illness generates similar literary mechanisms.

Keywords: Frigyes Karinthy, "diary of an illness", tumor, body image, body philosophy 